\title{
Al-Hīlah al-Shar'iyyah as a Method in Responding to Prayer Problems in Space
}

\author{
Siti Marhamah ${ }^{1}$, Mahsun Mahsun ${ }^{2}$ \\ 1,2Universitas Islam Negeri Walisongo Semarang, Indonesia \\ ${ }^{1}$ sitimrhmh20@gmail.com, ${ }^{2}$ mahsun@walisongo.ac.id
}

\begin{abstract}
This paper describes the prayer problem for Muslim astronauts in space and provides solutions using the al-hilah al-shar'iyyah method. This paper is qualitative with descriptive-analytic research methods with data sourced from the literature. This paper finds that with the al-hillah al-shar'iyyah method, Muslim astronauts can still carry outtheir obligations as a mukallaf. They get rukhsah (dispensation), both related to the direction of the qibla and the determination of prayer times. Rukhsah, as a result of the al-hilah alshar'iyyah method, helps Muslim astronauts in two conditions at once, first, in their position as scientists who carry out scientific missions. Second, in his position as a Muslim with his obligations to carry out the shari'ah.
\end{abstract}

Keywords: al-hīlah al-shar'iyyah; rukhșah; prayer in space; Muslim astronaut

\section{[]}

Tulisan ini bertujuan untuk mendeskripsikan permasalahan salat bagi astronot Muslim di luar angkasa dan memberikan solusi dengan menggunakan metode al-hillah al-shar'ïyyah . Tulisan ini bersifat kualitatif dengan metode penelitian deskriptif-analitik dengan data bersumber dari kepustakaan. Tulisan ini menemukan bahwa dengan metode al-hïlah alshar'iyyah, astronot muslim tetap dapat menjalankan kewajibannya sebagai seorang mukallaf. Mereka mendapatkan rukhsah (keringanan), baik yang berkaitan dengan arah kiblat maupun penentuan waktu salat. Rukhșah, sebagai hasil dari metode al-hïlah alshar'iyyah, membantu para astronot Muslim dalam dua kondisi sekaligus, pertama, dalam posisinya sebagai ilmuwan yang mengemban misi ilmiah. Kedua, dalam posisinya sebagai seorang muslim dengan kewajibannya menjalankan syariat.

Kata Kunci: al-hịlah al-shar'íyyah; rukhṣah; salat di luar angkasa; astronot Muslim 


\section{Introduction}

The evolution of science and technology is compatible with the times, human behavior, and habits. In Islam, the developments in humans, such as physical, mental, social, and emotional development, are seen as a unified whole and interrelated. The development that occurs to humans is progressive, getting more advanced, increasing, expanding, not happening suddenly and by chance. Physical aspect advancement of humans includes brain advancement, so that along with the physical promotion, cognitive abilities will continue to increase. It has implications for the betterment of science and technology that occurs on earth. ${ }^{1}$

The advancement that occurs to humans has implications for shifting human behavior, causing doubts regarding the law for the mukallaf (the accountable person). Primarily when the texts and ijtihād of the scholars do not regulate the behavior of the mukallaf. In addition, it is known that the nașs has stopped while the problem is continually growing. This fact requires efforts to develop applicable Islamic law by taking into account its locus and time. ${ }^{2}$

Responding to developments in all aspects of human life, scholars use the rules of fiqh (al-qawā'id al-fiqhiyyah) as the basis for establishing new fiqh. Ibn al-Qayyim al-Jawziyah, in this case, raised the rules of fiqh as follows.

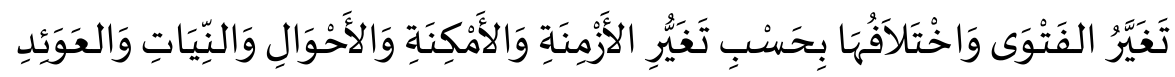

"Laws can change according to changing times, places, circumstances, intentions, and customs.".

The development of science and technology has paved the way for humans to do things that were previously impossible to become possible. One result of these developments, humans can travel to outer space. Long before space travel was possible, Allah had indicated that it was necessary. Allah states it in QS. 55: 33.

1 Imam Hanafi, "Perkembangan Manusia dalam Tinjauan Psikologi dan Al-Qur'an," IQ (Ilmu AlQur'an):Jurnal Pendidikan Islam 1, no. 1 (January 2018): 84-99, https://doi.org/10.37542/IQ.V1I01.7.

2 Mahsun Mahsun, "Rekonstruksi Pemikiran Hukum Islam Melalui Integrasi Metode Klasik dengan Metode Saintifik Modern," Al-Ahkam 25, no. 1 (April 2015): 5-6, https://doi.org/10.21580/ahkam. 2015.1.25.191.

3 A. Djazuli, Kaidah-Kaidah Fikih: Kaidah-Kaidah Hukum Islam dalam Menyelesaikan MasalahMasalah yang Praktis (Jakarta: Kencana, 2001), 14. 


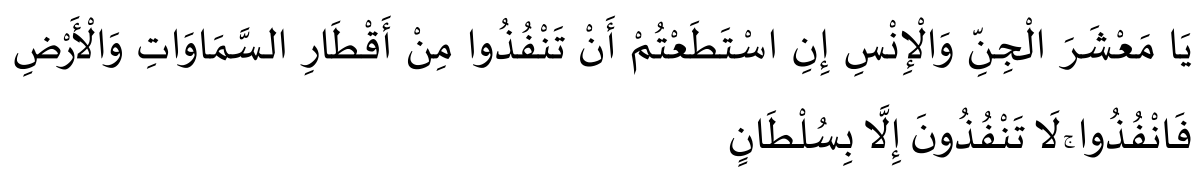

"O society of jinn and humans! If you can pass beyond the realms of the heavens and the earth, go ahead and pass. But you can pass only with permission."

Nazi Germany first realized the opportunity for space exploration in the 1930s-1940s through the idea of using rockets as long-range weapons. ${ }^{4}$ After World War II ended, a new conflict began between the United States and the Soviet Union, known as the 'Cold War.' Beginning in the 1950s, the two competed in the arena of space exploration and military firepower to prove each other's technological superiority. ${ }^{5}$ Until October 4, 1957, the first space mission was carried out by the Soviet Union in the launch of the Sputnik I Satellite. Then, the space mission that brought Yuri Gagarin was the world's first humancrewed mission, launched in 1961 by the Soviet Union. The United States demonstrated the success of the next space mission through the landing on the moon by Neil Armstrong in 1969.6 The success of the space mission was a pioneer in the sustainability of missions in outer space that was compatible with the times, science, and technology. After the cold war, the United States and Russia developed many countries in the space cooperation program. Islamic countries from Africa, the Middle East, and Asia are present as new colleagues. ${ }^{7}$

Sultan bin Salman Al Saud first initiated the journey of Muslim astronauts into space from Saudi Arabia on June 17, 1985. The existence of Muslim astronauts in space brought new challenges beyond their scientific missions. These namely religious practices must still be carried out in different places and conditions. Astronauts in space have many tasks, including conducting science

\footnotetext{
4 "A Brief History Of Space Exploration," Aerospace, 2018, https://aerospace.org/article/briefhistory-space-exploration.

5 “The Space Race,", History.com Editors, A\&E Television Networks, 2020, https://www.history. com/topics/cold-war/space-race.

${ }^{6}$ Neni Ruhaeni and Fariz Farikh Izadi, "The Outer Space Exploration Under International Space Law: An Islamic Point of View', in 2nd Socia; and Humaniora Research Symposium (SoRes 2019), vol. 409 (Bandung: Atlantis Press SARL, 2020),369-72, https://doi.org/10.2991/assehr.k.200225.077.

7 Cathleen S. Lewis, 'Muslims in Space: Observing Religious Rites in a New Environment', Astropolitics 11, no. 1-2 (2013), https://doi.org/10.1080/14777622.2013.802622.
} 
experiments on aircraft, launching satellites, and other missions. The spacecraft travels through space at 17,500 miles per hour at an altitude of about 220 miles. The spacecraft carrying the astronauts orbits the earth every 90 minutes. During orbiting the earth, astronauts will experience 45 minutes of the day and 45 minutes of night. So, the sun rises and sets 16 times a day. ${ }^{8}$

These fast sunrises and sunsets can confuse when the prayer time arrives and which direction the qibla is in when performing prayers. A worrying issue is how Muslim astronauts can find sufficient time and the correct position to perform the five daily prayers towards the Kaaba when a day in space passes every 90 minutes. The Qur'an and Hadith do not regulate the issue of prayer times and the direction of the qibla in outer space. Therefore, methods to solve the prayer problem in outer space for astronauts who carry out missions in outer space with the urgency of the development of science and technology have thus become an urgent need.

As a solution to the problem of prayer in space, this paper refers to the alhillah al-shar'iyyah method. A method used by Hanafi scholars in solving complex problems. This paper is a literature study using a descriptive-analytical method with a science and fiqh approach as a form of ijtihäd to respond to the contribution of Muslim astronauts in the world of space.

Based on the literature review, there have been several studies related to problem-solving methods with al-hillah al-shar'iyyah. However, there has been no research that integrates these methods to solve prayer problems in outer space. Previous research related to the implementation of worship of Muslim astronauts in space has not discussed the method of solving the problems of prayer in outer space. Therefore, the method of solving this problem becomes very important to explore. The result of this research is a method of solving the problem of prayer in outer space for Muslim astronauts who carry out missions in outer space.

\section{The Principle of Al-Hīlah al-Shar'iyyah}

Hīlah comes from the verb ḥāla-yaḥülu-ḥilatan wa maḥālan, which means to change, divert, and deceive. Hillah also comes from the word al-tahawwul, a

\footnotetext{
8 Sean Potter, 'NASA Astronauts to Answer Questions from STEM Students', 2021, http://www. nasa.gov/press-release/nasa-astronauts-aboard-space-station-to-answer-questions-from-stemstudents.
} 
particular form of the meaning of the word al-tașarruf wa al-a'mal which means the change of law from one condition to another. ${ }^{9}$ The plural form of the word al-hillah is al-hiyal which etymologically also means a reason for a mukallaf to avoid burdens and responsibilities. ${ }^{10}$ Meanwhile, in terms of terminology, according to Ibn Taymiyah, al-hillah is an ingenious way to get to a goal, good or bad. ${ }^{11}$ Ibn al-Qayyim al-Jawziyah stated that al-hilah is a unique action that causes the perpetrator to change from one state to another. The use of the word has developed into a more specific term by experiencing a narrowing of meaning, namely tricks or hidden ways that lead someone to achieve their goals and intentions. People can only do this method with unique skills. ${ }^{12}$

According to al-Shatibi, in terms, hillah can be interpreted as an act that is essentially permissible to do to cancel other laws. In the Big Indonesian Dictionary, hïlah is called kilah, which means all deceit, trickery, or made-up excuses. At the same time, al-shar'iyyah means law or regulation. So al-hillah alshar'iyyah is a tactic to change the form of the law with certain tricks. The goal is to avoid a legal obligation. If observed, hìlah can cause deviations.

Jurisprudence experts differ on the permissibility of hillah with their respective arguments as follows.

a. Legal basis for accepting al-hïlah al-shar'iyyah (QS. 38: 44)

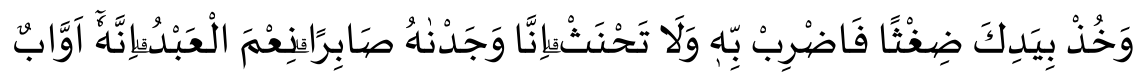

"And (it was said unto him): Take in thine hand a branch and smite therewith, and break not thine oath. Lo! We found him steadfast, how excellent a slave! Lo! he was ever turning in repentance (to his lord)."

Allah revealed the verse as a way out of the oath of the Prophet Job's whip. The oath started from one of his family members who did something he did not like. After the prophet Job swore, he regretted it, and then this

${ }^{9}$ Lutfi Nur Fadhilah, 'Al-Hilah al-Syar'iyyah dan Kemungkinan Penerapannya', Elfalaky: Jurnal Ilmu Falak 3, no. 1 (2019), http://journal.uin-alauddin.ac.id/index.php/elfalaky/article/download/9778/ 6795.

10 Mukhtar Zamzami, 'Hiyal Asy-Syar'iyah dalam Praktek Hibah dan Wasiat', Rakernas 2011 Mahkamah Agung dengan Pengadilan Seluruh Indonesia (Jakarta, September 2011), http://www.palolak.go.id/images/hiyal_asy_syariyah_dalam_praktek_hibah_dan_wasiat.pdf.

11 Muhamad Takhim, 'Metode Hilah (Dalih Hukum) dalam Fikih Muamalah Kontemporer', Jurnal Sosio Dialektika Jurnal Ilmu Sosial-Humaniora 4, no. 2 (31 December 2019), https://doi.org/ 10.31942/SD.V4I2.3128.

12 Fadhilah, 'Al-Hilah al-Syar'iyyah dan Kemungkinan Penerapannya'. 
verse came down as a way out for him. Allah ordered the Prophet Job to take as much grass as he had sworn. So that the Prophet Job can still carry out his oath, but in a way that is not painful. ${ }^{13}$

b. Legal basis of rejection of al-hìlah al-shar'iyyah (QS. 2: 9)

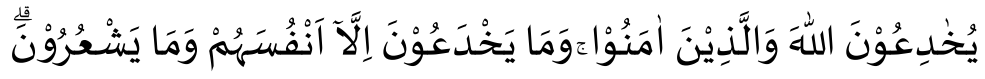

"They think to beguile Allah and those who believe, and they beguile none save themselves, but they perceive not."

Deceit in verse is an act or word with a motive to deceive. Bad intentions can be disguised so that they seem to have good intentions. The act of deceiving Allah can be confirmed by deceiving the believers. The deception committed by the hypocrites against the believers who believe in Allah, which the hypocrites deny, is considered directed at Allah. Nevertheless, the truth is, when the hypocrites deceive the Muslims, they are the ones who were deceived. The believers remain kind, as if they are not being deceived, even though they know it.

Hìlah is a form of the Hanafî School's response to changes in situations and conditions that result in changes in people's habits. Meanwhile, the Mālikī, al-Shāfi'ī, and Ḥanbalī schools oppose this concept. Here are some reasons for the opposition of the Mālikiyyah. ${ }^{14}$

1. The purpose of hìlah is contrary to the purpose of the sharī'ah.

2. Hîlah results in the evil that the sharīah prohibits

3. Hîlah is an annulment of the law.

The Hanābilah prohibiting the application of hillah is because of the fiqh justification guidelines that must be maintained. This prohibition is the same as the sadd al-dhari'ah theory (preventive action). The jurists set sadd al-dhari'ah to cover all means to achieve the result that is forbidden. In contrast, hillah is an action that can change a forbidden case to be permissible. Meanwhile, al-

${ }^{13}$ M. Quraish Shihab, Tafsir Al-Misbah Pesan, Kesan, dan Keserasasian Al-Qur'an (Jakarta: Lentera Hati, 2001).

14 Najib Ahmad, 'Analisis Penerapan Hilah Pada Fatwa Dewan Syariah Nasional - Majlis Ulama Indonesia (DSN MUI) tentang Murabahah Ijarah Muntahiyah Bi Al Tamlik (IMBT) dan Rahn' (Institute Agama Islam Negeri, 2020), http://repository.iainpurwokerto.acid/7023/. 
Shāfi'iyah emphasizes aspects of the primary mission of the Prophet as the bearer of the benefit of all humankind.

Abū Hanifah denied the lousy image of hillah. He did not allow the use of hìlah in makrūh actions, let alone cause wrong prejudice against others. It states that hillah is prohibited when used in the context of blatantly abolishing rules. In the Hanafi School, the purpose of hilah is to benefit the community, not to destroy the existing sharīah or legal provisions. Hïlah implicitly contains the principle of ease in carrying out sharia obligations but is not intended to abort other shari'ah obligations. Here are some rules regarding the application of hillah in the Hanafi school.

1. Hîlah aims to shift the legal burden that is too heavy to a lighter legal burden and more effective.

2. Hìlah aims to provide tolerance for customs in a place with no provisions in the texts.

3. Hillah is engineering to block someone from their rights while at the same time opening up opportunities for others to get their rights covertly (hillah). 'Alī Jad Al-Ḥaq classified hịlah into two, namely:

1. Hìlah is permissible: aimed at achieving the truth, rejecting injustice, and getting convenience. It is not intended to invalidate the law or damage the maqāṣid al-sharīah.

2. Hîlah, which is prohibited: aimed at canceling the law and maqāsid alshari'ah carried out with covert practices that are outwardly permitted by the sharīa $h$ but are forbidden in essence and eliminate the benefit. ${ }^{15}$

\section{The Problems of Prayer in Space}

Changes in conditions affect legal changes-one of the actual changes in the presence of Muslim astronauts. Space missions are an absolute necessity, given that they relate to life today. The launch of the satellite is one form. It is helpful for the navigation, telecommunications, meteorology, and military sectors. Some of these sectors are closely related to the objectives of the shari'ah in the form of protecting religion, soul, mind, lineage, and property. However, problems arise regarding the procedures for worship in outer space. Neither the

\footnotetext{
15 Takhim, 'Metode Hilah (Dalih Hukum) dalam Fikih Muamalah Kontemporer'.
} 
texts nor the ijtihād of classical scholars provides an answer to this problem. New ijtihād, therefore, needs to be done.

Astronauts are pinned to individuals who have flown in space. More specifically, astronauts refer to those from the United States, Canada, Europe, and Japan who travel into space. Soviets and Russians who traveled into space were known as cosmonauts. ${ }^{16}$ More importantly, until 2019, 11 Muslim astronauts have traveled to space on their scientific missions. The following is a list of Muslim astronauts and cosmonauts who have carried out missions in space:

1. Sultan ibn Salman ibn 'Abd al-'Azīz 'Alū Sa'ūd, as the first Muslim astronaut on the Space Shuttle mission STS-51-G Discovery in 1985. He is a Saudi Prince and Air Force pilot.17

2. Muhammad Faris, an Air Force pilot from Aleppo, Syria, flew to the Mir space station in 1987 as an astronaut researching the program Interkosmoson the Soyuz TM-3.

3. Musa Khiramanovich Manarov was the first Muslim astronaut from the Soviet Union. With two flights to the Soviet Mir space station in 1987 and 1990 on the Mir missions EO-3 and Soyuz TM-11.

4. Abdul Ahad Mohmand of Afghanistan was nominated for the Soviet program and flew to the space station on the MIR mission EP-3 in 1988.

5. Toktar Ongarbayuly Aubakirov, a paratrooper of the Kazakh Air Force, was born in the Soviet Republic but a Kazakhstan citizen. His only mission to space was on a Soyuz TM-13 for a seven-day excursion in October 1991 that did not coincide with Ramadan that year.

6. Aubakirov Talgat Amangeldyuly Musabayev, during his career as an astronaut, made two long-term trips in 1994 and 1998 with the Soyuz TM19 and MSI Soyuz TM-17 missions. One short-term mission was in 2001 with the Soyuz TM-32 mission.

7. Salizhan Shakirovich Sharipov, a pilot born in Kyrgyzstan and Uzbekistan ethnic. It is the only one of four to fly in space on an American shuttle and a Russian Soyuz. Selected for the cosmonaut corps shortly before the collapse of the Soviet Union, Shapirov's first mission in space was the Endeavor Space Shuttle STS-89, the eighth docking mission between the spacecraft

\footnotetext{
16 'Astronaut', in Britannica Online Encyclopedia, 2020.

17 Lewis, 'Muslims in Space : Observing Religious Rites in a New Environment'.
} 
and Russia's Mir in January 1998. The 10th Expedition to the ISS in 20042005.

8. Anousheh Ansari, an Iranian-American. During an eight-day, self-funded "tourist" space flight to the ISS, Ansari conducted a European Space Agencysponsored experiment with the Soyuz TMA-9 mission.

9. Sheikh Muszaphar Shukor successfully flew into space in October 2007 on the Soyuz TMA-11 mission. Shukor's flight as part of the crew of Expedition 16 to the ISS in October 2007 coincided with the last part of Ramadan, and he is best known for performing prayers in space.

10. Aidyn Aimbetov became the third Kazakh astronaut to go into space, himself launching into space on September 2, 2015 for the Soyuz TMA-18M.18

11. Hazza Al Mansoori, became one of the newest Muslim astronauts to go to space with the Soyuz-MS-15 mission. Hazza Al Mansoori was on a mission on September 25, 2019.

One of the pillars of prayer is to face the qibla, which is the direction of the Kaaba. However, the first obstacle, when the astronauts were in space with the earth's orbital speed of 17,500 miles per hour, Mecca was moving quickly under the spacecraft. The second obstacle, regarding prayer times. In general, Muslims pray five times a day. The problem is, astronauts experience a sunrise and sunset every ninety minutes as they orbit the earth. The fast-rising and setting of the sun can confuse the timing of prayers. The legal shift in the obligation to pray can only change regarding the time of prayer, not the place of prayer. Even though Muslim astronauts carry out science missions in space, there is no waiver of the obligation to perform prayers for a mukallaf. In a hadith, it is stated that whoever leaves the prayer, Allah will meet him in a state of anger.19

Fuqahä' differ between facing the direction of the Kaaba (jihät al-ka'bah) and facing the physical building of the Kaaba ('ayn al-ka'bah), especially for people who are far from the Kaaba. Epistemologically the meaning of qibla is facing. Meanwhile, according to the Ministry of Religion of the Republic of Indonesia, qibla is a specific direction for Muslims to face when performing prayers. In the Big Indonesian Dictionary, qibla means the direction to the Kaaba

\footnotetext{
18 Yohana Belinda, 'Bikin Bangga, 11 Astronaut Muslim Ini Sukses Ke Angkasa Luar', Liputan 6, 2020.

${ }^{19}$ M. Ikhtirozun Ni'am, 'Arah Kiblat di Planet Mars', Al-Marshad: Jurnal Astronomi Islam dan IlmuIlmu Berkaitan 2, no. 1 (2016): 12-21, http://dx.doi.org/10.30596\%2Fjam.v2i1.762.
} 
in Mecca (during prayer). It can be understood that the qibla direction means facing the Kaaba during prayer.

According to Hanafi scholars, the qibla direction for prayer is the Kaaba. Qibla direction for prayer for people who cannot see the Kaaba is facing the Kaaba (jihät al-ka'bah). ${ }^{20}$ Nevertheless, those who can see the Kaaba must face the physical building of the Kaaba ('ayn al-ka'bah). ${ }^{21}$

The Mālikī school believes that the direction of qibla when Muslims pray is the Kaaba. The majority of scholars of the Māilin school believe that in prayer, it is obligatory to face the Kaaba (jihät al-ka'bah) for people who cannot see the Kaaba. ${ }^{22}$ The Māiliki school of thought thinks facing the Kaaba is an obligation will be burdensome for anyone who cannot see the Kaaba directly. ${ }^{23}$ For those who can see the Kaaba, they must face the Kaaba building ('ayn al-ka'bah). ${ }^{24}$

Meanwhile, some scholars of al-Shāfi'iyah argue that in prayer, it is obligatory to face the Kaaba ('ayn al-ka'bah) for those who are near or far from the Kaaba. ${ }^{25}$ However, those who are far away and cannot see the Kaaba can use an estimate (zann). ${ }^{26}$ If someone far from the Kaaba knows the signs of the qibla, he is obliged to perform ijtihäd to know the qibla. ${ }^{27}$ Meanwhile, the direction of qibla based on the agreement of the Hanbali school of thought is the Kaaba. The qibla of prayer for people who can see the Kaaba is obligatory facing the physical building ('ayn al-ka'bah). ${ }^{28}$ Moreover, those far from the Kaaba must face the direction of the Kaaba building or where the Kaaba is located (jihät al-ka'bah).29

Fuqahä' also differ in opinion regarding prayer times. The noontime in the al-Shāfi'î school begins when the sun slips (zawāl al-shams). According to the jurists, the meaning of zawāl al-shams is a visible shift of the sun, not the actual

${ }^{20}$ Aboebakar Atjeh, Ilmu Fiqh Islam dalam Lima Mazhab (Jakarta: Islamic Research Institute, 1977).

${ }^{21}$ Achmad Jaelani et al., Hisab Rukyat Menghadap Kiblat (Fiqh, Aplikasi Praktis, Fatwa, dan Software), ed.Ahmad Izzudin, 1st ed. (Semarang: Pustaka Rizki Putra, 2012), 29-30.

22 Atjeh, Ilmu Fiqh Islam dalam Lima Mazhab.

${ }^{23}$ Ali Mustafa Yaqub, Kiblat Antara Bangunan dan Arah Ka'bah (Pustaka Darus-Sunnan, 2010).

24 Kutbuddin Aibak and Ahmad Munsonif, Metode Penentuan dan Akurasi Arah Kiblat MasjidMasjid di Tulungagung (Tulungagung: IAIN Tulungagung Press, 2018).

25 Aibak and Munsonif.

${ }^{26}$ Yaqub, Kiblat Antara Bangunan dan Arah Ka'bah.

27 Jaelani et al,, Hisab Rukyat Menghadap Kiblat (Fiqh, Aplikasi Praktis, Fatwa, dan Software).

28 Yaqub, Kiblat Antara Bangunan dan Arah Ka'bah.

${ }^{29}$ Jaelani et al., Hisab Rukyat Menghadap Kiblat (Fiqh, Aplikasi Praktis, Fatwa, dan Software). 
zawāl. It is because the zawāl happened before the zawāl zahir appeared. The end of noontime arrives when the shadow of an object is the same length as the object. ${ }^{30}$

According to the al-Shāfi'ì, Mālikī, and Ḥanbalī schools, the beginning of 'Așr time begins when the shadow of an object exceeds the length of the object. According to the Hanafi school, it begins when the shadow of an object is twice as long as the object. ${ }^{31}$

According to the al-Shāfi'i achool, the beginning of Maghrib time is from the time the sunsets. There are two opinions of al-Shāfi'i regarding the time of Maghrib. Qawl qadìm al-Shăfi'i states that the time of Maghrib continues until the disappearance of the red cloud (shafaq). Whereas in qawl jadìd, Maghrib time is only a short time since sunset. A stronger opinion is qawl qadim..$^{32}$

While the beginning of the time of Ishā' prayer, the majority of scholars in the al-Shāfi'i school agree on the beginning of the time of Isha' prayer time, that is, when the disappearance of al-shafaq al-ahmar (red cloud). While the beginning of the Maghrib prayer time, scholars agree that it starts at the second dawn (al-fajr al-thānī) or al-fajr al-șādiq (actual dawn). Al-fajr al-șādiq appearance is a white light that transversely follows the latitude of the horizon to the east. ${ }^{33}$

The first Muslim astronaut to carry out a mission in space was Sultan ibn Salman ibn 'Abd al-'Azīz Al-Sa'ūd. Its first mission was the Space Shuttle aboard the shuttle STS-51-G on June 17,1985, as part of a seven-member international crew. He became a representative of the Arab Satellite Communications Organization (ARABSAT) and was tasked with deploying the organization's satellite, ARABSAT-1B. While in space, he conducted research experiments, including the ionized gas experiment conducted by other members of the Saudi royal family for Ph.D. dissertations and experiments on mixing oil and water when mixed in zero gravity. The space shuttle that brought him landed back on earth on June 24,1985, after completing its mission in 7 days 1 hour 38 minutes

\footnotetext{
30 Arwin Juli Rakhmadi, Pengantar Ilmu Falak: Teori, Praktik, dan Fikih, 1sted.(Depok: RajaGrafindo Persada, 2019).

31 Watni Marpaung, Pengantar Ilmu Falak, 1sted. (Jakarta: Prenadamedia Group, 2015).

32 Rakhmadi, Pengantar Ilmu Falak: Teori, Praktik, dan Fikih.

33 Marpaung, Pengantar Ilmu Falak.
} 
52 seconds. ${ }^{34}$ While in outer space, he positioned himself as a traveller who performs the jamán (three times a day) prayers with fixed prayer times in Florida, USA. 35 When praying, he faces anywhere. He has difficulty facing the Kaaba and obstacles in performing the prayer movement in zero gravity conditions. ${ }^{36}$ In 2006, Malaysia sent its first astronauts to the ISS. In October, he was Sheikh Muszaphar Shukor Muzapar with 15 crew who took off to the ISS with the Soyuz TMA-11 plane from the Baikonur Cosmodrome station, Kazakhstan 10, 2007. The sending of Muzapar to the ISS became the forerunner of new ijtihād to answer the problems of prayer in outer space.

\section{Al-Hīlah al-Shar'iyyah as a Legal Solution Facing the Qibla Direction in Outer Space}

The fatwa issued by ANGKASA indicates the existence of rukhșah (dispensation). Rukhșah can be carried out if there are difficulties in carrying out worship. This difficulty is like what happens in the implementation of prayers in outer space. It is difficult to determine the qibla direction and determine prayer times. Forcing facing the Kaaba can result in losses, both for scientific missions and for the salvation of souls. This difficulty is classified as a severe type because the determination is different from what is expected on earth. When the implementation of 'azimah (global law) causes harm, then rukhșah is enforced as part of the rights of Muslims in difficulty. ${ }^{37}$

In order to fulfil the public interest, Islamic law responds with the process of renewing ijtihād. There are three reasons Islamic law can fulfil the public interest:

1. Islamic law can change according to the atmosphere, place, circumstances, intentions, and habits.

34 The Editors of Encyclopaedia Britannica, 'Sultan Ibn Salman Al Saud ', Encyclopedia Britannica, 23 June 2021, https://www.britannica.com/biography/Sultan-ibn-Salman-Al-Saud.

35 Lazuardhi Utama and Misrohatun Hasanah, 'Astronot Muslim Ternyata Bisa Salat dan Puasa di Luar Angkasa', 12 May 2021, https://www.viva.co.id/digital/digilife/1372246-astronot-muslimternyata-bisa-salat-dan-puasa-di-luar-angkasa.

36 Elin Yunita Kristanti, "17-6-1985: Kisah Astronot Muslim Pertama di Luar Angkasa" (Liputan 6, 2015), https://www.liputan6.com/global/read/2253350/17-6-1985-kisah-astronot-muslimpertama-di-luar-angkasa.

37 T. M Hasbi Ash-Shiddieqy, Pengantar Hukum Islam (Jakarta: Bulan Bintang, 1981), vols II; 211215. 
2. Islam legitimizes law enforcement through the qiyas method or with sound reasoning.

3. The use of reason and qiyas does not conflict with the corresponding texts.

These three reasons are intended to fulfil the public interest and for the benefit of humankind and missions to outer space for Muslim astronauts to fulfil the interests and benefits of the development of science and technology. In this case, Islamic law can adapt to the development of science and technology in line with the public interest. ${ }^{38}$

New ijtihäd is needed as an effort to actualize Islamic law. As is well known, the development of conditions and situations also influences legal decisions. Answering new problems that were not found in the past is an absolute necessity. If in the past there was no prayer problem in space, now it is a reality. This renewal is needed so that Islamic law is always flexible for every situation (șālih li kulli zamān wa makān). One of the efforts is the hillah method. It is intended to give rukhșah to customs in outer space, a place and phenomenon with no provisions in the texts and old ijtihād. It becomes a method to lighten the legal burden of Muslim astronauts as a mukallaf who is carrying out a mission in outer space while still carrying out his obligations. So that Muslim scientists can continue to contribute to the development of science and technology.

The problem of determining the qibla direction for Muslim astronauts in space is overcome by the al-hilah al-shar'iyyah method. So that Muslim astronauts are not fully charged with the obligation to face the Kaaba when praying. The transfer of the legal burden was due to the difficulty in determining the exact position of the Kaaba. That is because of the orbital speed of the space station concerning the earth. The hilah method of solving the problem is tolerant because Muslim astronauts are in space. With this method, astronauts can still perform prayers with a tolerance of ease in determining the qibla direction. This facility does not invalidate and destroy the law because behind the convenience received, Muslim astronauts carry the mandate and responsibility to complete missions that are beneficial to all humans.

Prayers in outer space can be performed by praying on a vehicle. Prayers that are performed can face where the vehicle is headed. Abū Hanifah and alShāfi'i allowed prayer in a vehicle and did not distinguish between an average

${ }^{38}$ Ash-Shiddieqy, Pengantar Hukum Islam. 
trip and a journey to war. In a narration, Ibn 'Umar said he once prayed to face which direction his vehicle was facing. He said that the Prophet had done that too. ${ }^{39}$ In a narration, Ibn Umar was asked about the khawf prayer (prayer in war conditions). He said that if the situation was getting scary, they prayed on foot, some were driving, some were facing the qibla, and some were not facing the qibla. ${ }^{40}$

A hadith narrated by Bayhaqi that the Prophet said that Baytullah (Kaaba) is the qibla for people in the Grand Mosque. Masjīd al-Harm is qibla for people in Makkah. Mecca is the qibla for all people who are far from Mecca. The hadith indicates that the qibla for a Muslim is the Kaaba or where the Kaaba is located. So, Muslim astronauts can perform prayers by facing the earth where the Kaaba is or projecting towards it if there is an obstacle in the way. ${ }^{41}$

The Malaysian Space Agency once held a seminar with the theme "Seminar on Islam and Living in Space" with 150 scientists and scholars. The seminar discussed the fatwa for a Muslim to perform worship in outer space. ${ }^{42}$ The existing fatwa is meant to help future Muslim astronauts. ${ }^{43}$ The Malaysian National Fatwa Council has approved guidelines for Performing worship on the International Space Station. The fatwa states that the direction of qibla for astronauts is to face the Kaaba, projecting the Kaaba, aiming at the earth, or anywhere. Mathematically, astronauts can position the ISS and Mecca on the same imaginary plane by assuming that the earth below the ISS is the Kaaba or projecting the Kaaba into space. ${ }^{44}$

\section{Al-Hīlah al-Shar'iyyah in Determining the Prayer Times in Outer Space}

The time for prayer has entered one of the conditions for a valid prayer. However, according to the time specified in fiqh, consistent performing prayers

\footnotetext{
39 Ibn Kathir, Tafsir Ibnu Kasir, ed. Bahrun Abu Bakar (Bandung: Sinar Baru Algensindo, 2000), vols I; 858.

40 Kathir, Tafsir Ibnu Kasir.

${ }^{41}$ Ni'am, "Arah Kiblat di Planet Mars."

42 Arifina Budi, 'Salat di Luar Angkasa', 8 March 2017, https://tirto.id/salat-di-luar-angkasa-ckkQ.

43 'Muslims in Outer Space', accessed 24 September 2021, https://rpl.hds.harvard.edu/religioncontext/case-studies/technology/muslims-outer-space.

44 'A Guideline of Performing Ibadah at the International Space Station (ISS)', n.d., https://www.wired.com/images_blogs/wiredscience/files/a_guideline_ibadah_at_iss.doc\#: :text=Ib adah in this guideline include,caring of the deceased and; N. Fischer, 'Islamic Religious Practice in Outer Space', ISIM Review 22, no. 1 (2008):39-39, https://hdl.handle.net/1887/17252.
} 
can bring difficulties for Muslim astronauts in space. The orbital speed of the space station to the earth is so fast that the sun rises and sets every 90 minutes. If the prayer time for a Muslim astronaut is determined based on the sun's movement in space, he must perform five fard prayers every 90 minutes. It is feared that the frequency of dense prayers can interfere with the implementation of astronaut missions and can threaten life safety.

The problem of determining prayer times in space can be solved by the alhillah al-shar'iyyah method. With this method, astronauts can perform prayers with tolerance in determining prayer times. Moreover, it carries a critical mission for the development of science and technology in the future. The hillah method can transfer the legal burden of the obligation to perform prayers according to the time of the sun's movement in outer space. Tolerance for unusual phenomena is more effective to apply. The law regarding the time of prayer in space is not regulated in the texts, so new ijtihād is needed to accommodate Muslim astronauts who contribute to space.

Based on the fatwa that the National Fatwa Council has approved of Malaysia, prayer times in space are guided by prayer times at the launch station area. It means Muslim astronauts do not need to determine prayer times based on the sun in space. Astronauts only need to communicate prayer times with the crew of the launch station on earth. With the hillah method, Muslim astronauts get rukhșah in the form of doing something that has not been in time or has passed.

Contemporary scholars agree that prayer times for astronauts in space can refer to prayer times in Mecca, Cape Canaveral (launch station), and Greenwich time. Mecca prayer times can be used as a reference for astronauts because of their privilege as the Prophet first received orders to perform prayers. While the reason for using Greenwich time is that it is based on Greenwich time in determining NASA's daily schedule, including flights into space. ${ }^{45}$

\section{Conclusion}

New ijtihād is always needed to accommodate new situations and conditions. One of the latest is the existence of Muslim astronauts who contribute to the world of space that is compatible with the evolution of science and technology. The problem-solving method with a scientific and fiqh approach

${ }^{45}$ Ahmad Sarwat, Waktu Shalat, ed. Fatih (Jakarta Selatan: Rumah Fiqih Publishing, 2018), 42-47. 
in this research is a new thing in the discourse on the problematics of prayer in outer space. The al-hillah al-shar'iyyah method can be a solution for Muslim astronauts who carry out science missions in space. With it, they get rukhșah. Muslim astronauts can still carry out missions for the benefit of humankind; at the same time, they can still carry out their obligations as a mukallaf.[a]

\section{BIBLIOGRAPHY}

'A Brief History of Space Exploration'. Aerospace, 2018. https://aerospace.org/ article/brief-history-space-exploration.

'A Guideline of Performing Ibadah at the International Space Station (ISS)', n.d. https://www.wired.com/images_blogs/wiredscience/files/a_guideline_ ibadah_at_iss.doc\#: :text=Ibadah in this guideline include,caring of the deceased and.

Ahmad, Najib. 'Analisis Penerapan Hilah Pada Fatwa Dewan Syariah Nasional Majlis Ulama Indonesia (DSN MUI) tentang Murabahah Ijarah Muntahiyah Bi Al Tamlik (IMBT) dan Rahn'. Institute Agama Islam Negeri, 2020. http://repository.iainpurwokerto.ac.id/7023/.

Aibak, Kutbuddin, and Ahmad Munsonif. Metode Penentuan dan Akurasi Arah Kiblat Masjid-Masjid di Tulungagung. Tulungagung: IAIN Tulungagung Press, 2018.

Ash-Shiddieqy, T. M Hasbi. Pengantar Hukum Islam. Jakarta: Bulan Bintang, 1981.

Atjeh, Aboebakar. Ilmu Fiqh Islam dalam Lima Mazhab. Jakarta: Islamic Research Institute, 1977.

Belinda, Yohana. 'Bikin Bangga, 11 Astronaut Muslim Ini Sukses ke Angkasa Luar'. Liputan 6, 2020.

Budi, Arifina. 'Salat di Luar Angkasa', 8 March 2017. https://tirto.id/salat-diluar-angkasa-ckkQ.

Djazuli, A. Kaidah-Kaidah Fikih: Kaidah-Kaidah Hukum Islam dalam Menyelesaikan Masalah-Masalah yang Praktis. Jakarta: Kencana, 2001.

Fadhilah, Lutfi Nur. 'Al-Hilah Al-Syar'iyyah dan Kemungkinan Penerapannya'. Elfalaky: Jurnal Ilmu Falak 3, no. 1 (2019). http://journal.uin-alauddin. ac.id/index.php/elfalaky/article/download/9778/6795. 
Fischer, N. 'Islamic Religious Practice in Outer Space'. ISIM Review 22, no. 1 (2008): 39-39. https://hdl.handle.net/1887/17252.

Hanafi, Imam. 'Perkembangan Manusia dalam Tinjauan Psikologi dan AlQur'an'. IQ (Ilmu Al-Qur'an): Jurnal Pendidikan Islam 1, no. 01 (1 January 2018): 84-99. https://doi.org/10.37542/IQ.V1I01.7.

History.com Editors. 'The Space Race', 2020. https://www.history.com/topics/ cold-war/space-race.

Jaelani, Achmad, Anisah Budiwati, Encep Abdul Rojak, Faqih Baidhawi, Mahya Laila, Hasna Tuddar Putri, Muhammad Manan Ma'nawi, et al. Hisab Rukyat Menghadap Kiblat (Fiqh, Aplikasi Praktis, Fatwa, dan Software). Edited by Ahmad Izzudin. 1st ed. Semarang: Pustaka Rizki Putra, 2012. http://eprints.walisongo.ac.id/id/eprint/6807/.

Kathir, Ibn. Tafsir Ibnu Kasir. Edited by Bahrun Abu Bakar. Bandung: Sinar Baru Algensindo, 2000.

Kristanti, Elin Yunita. '17-6-1985: Kisah Astronot Muslim Pertama di Luar Angkasa'. https://www.liputan6.com/global/read/2253350/17-61985-kisah-astronot-muslim-pertama-di-luar-angkasa.

Lewis, Cathleen S. 'Muslims in Space: Observing Religious Rites in a New Environment'. Astropolitics 11, no. 1-2 (2013). https://doi.org/10.1080/ 14777622.2013.802622.

Mahsun, Mahsun. 'Rekonstruksi Pemikiran Hukum Islam Melalui Integrasi Metode Klasik dengan Metode Saintifik Modern'. Al-Ahkam 25, no. 1 (25 April 2015): 1. https://doi.org/10.21580/ahkam.2015.1.25.191.

Marpaung, Watni. Pengantar Ilmu Falak. Jakarta: Prenadamedia Group, 2015.

'Muslims in Outer Space'. Accessed 24 September 2021. https://rpl.hds.harvard. edu/religion-context/case-studies/technology/muslims-outer-space.

Ni'am, M. Ikhtirozun. 'Arah Kiblat di Planet Mars'. Al-Marshad: Jurnal Astronomi Islam dan Ilmu-Ilmu Berkaitan 2, no. 1 (2016): 12-21. http://dx.doi.org/ 10.30596\%2Fjam.v2i1.762.

Potter, Sean. 'NASA Astronauts to Answer Questions from STEM Students', 2021. http://www.nasa.gov/press-release/nasa-astronauts-aboardspace-station-to-answer-questions-from-stem-students.

Rakhmadi, Arwin Juli. Pengantar Ilmu Falak: Teori, Praktik, Dan Fikih. 1st ed. Depok: PT. RAJAGRAFINDO PERSADA, 2019.

Ruhaeni, Neni, and Fariz Farikh Izadi. 'The Outer Space Exploration Under International Space Law: An Islamic Point of View'. In 2nd Socia; and 
Humaniora Research Symposium (SoRes 2019), 409:369-72. Bandung: Atlantis Press SARL, 2020. https://doi.org/10.2991/assehr.k.200225. 077.

Sarwat, Ahmad. Waktu Shalat. Edited by Fatih. Jakarta Selatan: Rumah Fiqih Publishing, 2018.

Shihab, M. Quraish. Tafsir Al-Misbah Pesan, Kesan, dan Keserasasian Al-Qur'an. Jakarta: Lentera Hati, 2001.

Takhim, Muhamad. 'Metode Hilah (Dalih Hukum) dalam Fikih Muamalah Kontemporer'. Jurnal Sosio Dialektika Jurnal Ilmu Sosial-Humaniora 4, no. 2 (31 December 2019). https://doi.org/10.31942/SD.V4I2.3128.

The Editors of Encyclopaedia Britannica. 'Sultan Ibn Salman Al Saud '. Encyclopedia Britannica, 23 June 2021. https://www.britannica.com/ biography/Sultan-ibn-Salman-Al-Saud.

Utama, Lazuardhi, and Misrohatun Hasanah. 'Astronot Muslim Ternyata Bisa Salat dan Puasa di Luar Angkasa', 12 May 2021. https://www.viva.co.id/ digital/digilife/1372246-astronot-muslim-ternyata-bisa-salat-dan-puasa-di-luar-angkasa.

Yaqub, Ali Mustafa. Kiblat Antara Bangunan dan Arah Kakbah. Jakarta: Pustaka Darus-Sunnah, 2010.

Zamzami, Mukhtar. 'Hiyal Asy-Syar'iyah dalam Praktek Hibah dan Wasiat'. Rakernas 2011 Mahkamah Agung dengan Pengadilan Seluruh Indonesia. Jakarta, September 2011. http://www.pa-lolak.go.id/images/hiyal_asy_ syariyah_dalam_praktek_hibah_dan_wasiat.pdf. 